\title{
The Effect of No Plastic Straw Movement on Vokasi Universitas Indonesia Students Attitude
}

\author{
Nia Murniati \\ \{n.murniati@ui.ac.id\} \\ Vocational Program, Universitas Indonesia, Indonesia
}

\begin{abstract}
No plastic straws movement may seem like a small thing, but this movement is committed to preserving the environment by reducing plastic waste from straws. Disposable plastic straws have a large environmental footprint. In fact, more than 175 billion straws are filtered into landfills and pollute the ocean every year. Plastic straws ranked fifth on the list of the top 10 garbage items collected in the ocean. This research is quantitative explanative, the data obtained using purposive sampling technique on Vokasi Universitas Indonesia (UI) students as many as 137 respondents. Based on testing the independent variables (positive image, socially accepted tactics and socially acceptable goals) on attitudes using multiple linear regression analysis obtained the results of research simultaneously these three variables have a positive and significant effect on the attitudes of students of Vokasi UI.
\end{abstract}

Keywords: environmental health, health promotion, social movement

\section{Introduction}

The Government of Indonesia proclaims Waste Care Day every February 21st, this was motivated by the tragic events of February $21^{\text {st }} 2005$ over the landslide incident at the Leuwigajah Landfill, West Java. Tens of tons of garbage that piled up at the Leuwigajah landfill at that time hit the housing of the surrounding population, carrying 143 fatalities and hundreds of others homeless. ${ }^{[1]}$

Indonesia is ranked as the second largest contributor of waste after China. This means that if there is a flood or other environmental pollution in Indonesia, it is already an unavoidable consequence. Based on these facts, minimizing waste should be an obligation for us as the people of Indonesia. The waste minimization program is realized in various positive movements such as zero waste, plastic bag diet, 3R system (Reuse, Reduce, and Recycle) and no plastic straw movement. ${ }^{[2]}$

No plastic straw movement invites everyone to refuse and no longer use disposable plastic straws while enjoying a drink. This movement was initially implemented by one of KFC's fast food chicken outlets since 2017. The movement no longer provides direct smallsized plastic straws by removing the straw dispenser. Plastic straws are only given if the consumer really needs them and ask the waiter directly. Initially, this movement was only applied to six outlets. Gradually, this action expanded to 233 outlets in Greater Jakarta at the end of 2017, and became a national movement. As a result, the movement without plastic straws succeeded in reducing the use of plastic straws by 45 percent of the total sales of an average of 5 million drinks per month for the Greater Jakarta area alone. The successful 
movement without plastic straws in Indonesia was adopted by neighboring Singapore. This movement is now also being studied for imitation by the Philippines and Australia. Based on press statements quoted from Channel News Asia, this movement aims to reduce 7.8 metric tons of disposable plastic straws a year. Nationally, the movement is expected to reduce the use of plastic straws by 100 percent in the next five years. ${ }^{[3]}$

\subsection{No Plastic Straw Movement}

No Plastic Straw Movement departs from the abundance of plastic waste in the world. Plastic straw waste is the fifth largest contributor to plastic waste in the world. Indonesia is one of the top contributors to the world's top 4 plastic straw straws. Plastic waste is still a big problem for the environment. To overcome this, various activities to reduce the problem of plastic waste were carried out, one of which was the movement without straws. Different from other plastic waste, this plastic straw waste tends to be neglected because of its small size and has no sale value for recycling. ${ }^{[4]}$

On average, each person uses disposable straws 1-2 times each day, and the estimated use of straws in Indonesia every day reaches 93,244,847 sticks. It comes from restaurants, packaged drinks and other sources (packed straw). One of the movements shown not to use plastic straws is the KFC fast food restaurant. Now there is no more supply of plastic straws except for those with special needs. Because disposable straws are generally made of polypropylene type plastic that is durable. So that it does not degrade naturally, the longer it becomes small granules called microplastics which are very dangerous for the marine ecosystem. ${ }^{[5]}$

Report from the World Bank, Indonesia is ranked second as the largest plastic waste producing country in the world, after China. In 2010, Indonesia had a coastal population of 187.2 million who lived within 50 kilometers of the coast, and annually produced 3.2 million tons of waste. The rubbish is not well managed, so it is estimated to cause leakage of 0.48 to 1.29 million metric tons of plastic waste per year into the ocean. Plastic waste is always a complicated problem. Plastic straw waste is one of the five most common types of plastic waste. In 2018, the Divers Clean Action (DCA) organization said that plastic straw waste in Indonesia could reach 93.2 million per day. Even though it only has a length of about $10 \mathrm{~cm}$, it takes 500 years for the plastic straw to decompose into micro plastic. ${ }^{[6]}$

Micro plastic can enter the digestive system of animals, especially fish in the sea because they consider plastic flakes as plankton (fish food ingredients). In the body of the fish, the micro plastic does not decompose and when the fish is consumed by humans, the edges of the plastic will also be collected in the human body. Based on the Gemass Indonesia survey in 2017 on Pulau Harapan Island and Kepulauan Seribu there is rubbish in the sea resulting in the amount of fish stocks continues to decrease. This also triggers a veiled nutrient deficiency in the community on the island. ${ }^{[7]}$

Besides having an impact on marine life, it turns out that plastic straws have a dangerous health impact when we use it every day, namely flatulence and gassing. The habit of using plastic straws makes us swallow more air, especially if we use it when consuming soft drinks. Without us knowing, using a straw when drinking also makes us swallow dangerous chemicals that are used when making plastic straws, straws are made from polypropylene. Although considered a safe material, in several studies it was mentioned that this material can affect the hormone estrogen, especially if exposed to heat or UV light. ${ }^{[8]}$ 


\subsection{Plastic Waste}

The use of plastic has become a part of everyday human life. Its light and strong nature makes plastic practical. Without realizing it, plastic waste can threaten health and environmental balance. The world has a very serious problem regarding the amount of plastic waste produced. Basically, most of the plastic waste on earth is not recycled, meaning that it will not be reused. Considering that it is certainly very worrying if one day our earth is filled with plastic. ${ }^{[9]}$

The Ministry of Environment and Forestry said that plastic waste has increased in the last decade, from $11 \%$ in 2005 to $15 \%$ in 2015 . This is very concerning for environmental health because plastic waste requires 100 years to decompose. If the plastic waste is not recycled properly, it will be left into the sea which can certainly damage the marine ecosystem. Estimates of global plastic production are around 335 to 400 million tons annually and around 8 million metric tons of plastic waste enter land and sea each year. This plastic waste does not really disappear but only breaks down into smaller parts and is often accidentally digested by wildlife or even humans. ${ }^{[10]}$

When asked why do humans love plastic? The answer is very easy, because this material is cheap, easily produced in large volumes, and durable. Plastic durability is one of the main problems, because it takes a very long time to be degraded. The use of plastic materials is very common for example as packaging for drinks, food, bags, toys and so forth. Therefore it feels very reasonable if we want to fight the consumption of plastic, starting from the smallest and disposable plastic straws. As many as 93 million plastic straws are used and disposed of every day in Indonesia. Very fantastic number isn't it? ${ }^{[11]}$

Issues related to the impact of plastic waste and plastic straws at least become something that is worrying and frightening at this time if not quickly addressed. Overcoming the problem of waste for the world community is one of the targets that must be done. Developed countries like the UK impose a ban on the use of plastic. Even in China recently stopped to buy plastic goods from developing countries. ${ }^{[12]}$

\subsection{Social Movement}

Social movement is a form of joint action aimed at social reorganization, both neatly organized and liquid and informal. Social movement is a movement that is carried out jointly in order to achieve the goals that are equally desired by the group or in other words the social movement is a collective action to achieve the desires that become common goals. The theoretical social movement is a movement that is built based on community initiatives with the aim of making demands on changes in institutions and policies from the government that are considered to be or are no longer in accordance with the wishes of some people. Social movements are born from situations in society because of injustices and arbitrary attitudes towards society. In other words, social movements are born from reactions to something that is not desired by the people or want a policy change because it is considered unfair. Social movement is a collective effort to pursue a common interest or movement to achieve common goals through collective action outside the scope of established institutions. ${ }^{[13]}$

\section{Method}

This study used a purposive sample with subjects of this study were 137 students in Vokasi UI. Questionnaires with a five-point Likert Scale for Positive Image (PI) 
variables, Socially Accepted Tactics (SAT), and Socially Acceptable Goals (SAG). Students attitude variable using a two-point Binary Scale. Data analysis using Multiple Logistic Regression which aims to show the pattern of relationships between the dependent variables that are binary $(0=$ negative attitude or $1=$ positive attitude $)$ with more than one independent variable (PI, SAT, and SAG).

\section{Results}

The results of the analysis of the effect of Positive Image (PI), Socially Accepted Tactics (SAT), and Socially Acceptable Goals (SAG) on the attitudes of Vokasi UI students display multiple linear regression Equations.

$$
\mathrm{Y}=3,431+0,245 \mathrm{X} 1-0,083 \mathrm{X} 2+0.037 \mathrm{X} 3+\mathrm{e}
$$

Based on the results of these equations, it shows that PI, SAT and SAG have an influence on the attitudes of Vokasi UI students. The analysis showed that the calculated $\mathrm{F}$ value was $2.770>\mathrm{F}$ table 2.67 and the $\mathrm{p}$-value or significance was $0.044<0.05$. Thus PI, SAT and SAG simultaneously have a significant influence on the attitudes of Vokasi UI students.

The Effect of Positive Image (PI) on student attitudes based on the results of partial tests ( $\mathrm{t}$ test) obtained $\mathrm{t}$ count value of 2.691>t table 1.977 shows the positive image variable has an influence on the attitudes of students of Vokasi UI. The influence of Socially Accepted Tactics (SAT) on students' attitudes obtained t count value 2.906> t table 1.977 shows that movement tactics / strategies have an influence on the attitudes of students of Vokasi UI. Based on the results of this analysis it can be concluded that social movement strategies are considered to have a high tendency to be able to attract the attention of the target.

The influence of Socially Acceptable Goals (SAG) on students' attitudes obtained t count value of 2.456>t table 1.977 shows that SAG ad execution has an influence on student attitudes. Interpretation of the variables as a whole based on the results of the $F$ test shows the calculated $F$ value $2.770>F$ table 2.67 with a significance of 0.044 . Thus, if the PI, SAT and SAG variables are combined together they have a significant effect on the attitudes of Vokasi UI students. Based on the results of the analysis of the coefficient of determination can be seen that the coefficient of determination (adjusted R2) obtained by 0.038 . This means that the PI, SAT and SAG variables only have an effect of $3.8 \%$ on the attitudes of Vokasi UI students, while the rest are influenced by other factors not included in this study.

\section{Discussion}

At present there are so many public actions and efforts to eliminate the use of plastic straws. Beginning with giant KFC companies followed by Mc. Donald and Starbucks have banned the use of plastic straws in some of their outlets. In addition, airlines, hotel and restaurant chains also flocked to leave the trend of using plastic straws. Data and statements that are straightforward and dramatic, including predictions that the amount of 
plastic will overtake fish in the ocean by 2050 were welcomed by governments, large multinational companies and community members. Such statements are indeed 100 percent inaccurate, but the impact is felt. Daily use of straws is reduced. ${ }^{[14]}$

With so many recent "no-straw" efforts, there is an "no-no-straw" rhetoric that rejects the movement for a variety of reasons. Disability rights activists, for example, speak out about the prohibition of plastic straws. Some people with disabilities need a straw to drink because they have problems swallowing or cannot lift or hold a glass. Various alternatives to plastic straws have also emerged as practical solutions, such as straws made of silicon, paper, corn starch, bamboo, glass, or stainless steel. In the end, consumers have ethical choices to make: planet or plastic? ${ }^{[15]}$

Adam Minter, an opinion columnist who often writes about recycling and similar things, argues that the ban on plastic straws ignores the real plastic problem. Minter argues that if all plastic straws drift into the sea, it only accounts for about 0.03 percent of the plastic waste that enters the ocean each year. Proponents of the ban on plastic straws do not completely disagree, but argue that disposing of plastic straws is a good first step and a simple way of conserving waste and the sea. ${ }^{[16]}$

In the short term, eliminating plastic straws will not save the world. But this is a good start towards changing expectations. The commitment to explore additional options to further reduce the use of disposable items is carried out by Ben \& Jerry's. ${ }^{[17]}$ Adam Minter and Ben \& Jerry's have similar behavior with UI students. They both pay attention to the No straw movement. They think this is a small step for a big goal, and they start from themselves today.

\section{Conclusion}

Many practical ways that can be done to reduce plastic waste, such as a plastic bag diet, carrying a replacement tumbler for disposable bottled water and not using plastic straws. Apart from the pros and cons of plastic straws, no straw movement has had a positive influence on the changing attitudes of Vokasi UI students. Positive image, Socially Accepted Tactics and Socially Acceptable Goals (SAG) of this movement have proven to be empowered to build awareness in environmental preservation. Students as agents of change play an important role in the success of this movement. Change will not occur if it is not built by intellectuals first, such as the problem of plastic waste today, building awareness and active participation in positive movements is the key to environmental sustainability.

\section{References}

[1]. Greeners. https://www.greeners.co/agenda-hari-lingkungan-hidup-februari/hari-peduli-sampahnasional/ accessed date September, $9^{\text {th }} 2019$

[2]. CNN Indonesia. https://www.cnnindonesia.com/gaya-hidup/20160222182308-277112685/indonesia-penyumbang-sampah-plastik-terbesar-ke-dua-dunia acceseed date September, $9^{\text {th }} 2019$

[3]. CNN Indonesia. https://www.cnnindonesia.com/gaya-hidup/20180629142643-282310154/gerakan-tanpa-sedotan-cara-baru-kurangi-sampah-plastik acceseed date September, $9^{\text {th }}$ 2019 
[4]. Ghostlight coffee in dayton joins anti-plastic straw movement. (2018, Jul 26). TCA Regional News Retrieved from https://remotelib.ui.ac.id:2076/docview/2076215778?accountid=17242

[5]. Lib UI. https://remote-lib.ui.ac.id:2076/docview/2158390661?accountid=17242

[6]. Williams, L. (2017, Mar 16). Restricting use of plastic straws the latest trend to clean up beaches, ocean. TCA Regional News Retrieved from https://remotelib.ui.ac.id:2076/docview/1877897623?accountid=17242

[7]. Kompasiana.https://www.kompasiana.com/yannuarwira0275/5cdf31f595760e77d70ada46/dam pak-sedotan-plastik-terhadap-lingkungan-dan-kesehatan-di-indonesia?page=all acceseed date September, $9^{\text {th }} 2019$

[8]. Williams, L. (2017, Mar 16). Straws stir the anti-plastics movement. TCA Regional News Retrieved from https://remote-lib.ui.ac.id:2076/docview/1877944459?accountid=17242

[9]. Jiang, L., Dami, I., Mathers, H. M., Dick, W. A., \& Doohan, D. (2011). The effect of straw mulch on simulated simazine leaching and runoff. Weed Science, 59(4), 580-586. Retrieved from https://remote-lib.ui.ac.id:2076/docview/900127241?accountid=17242

[10].https://nasional.kontan.co.id/news/sampah-plastik-menunjukan-tren-peningkatan-dalam-10tahun-terakhir acceseed date September, $9^{\text {th }} 2019$

[11].EB Furgurson, I.II. (2018, Feb 23). The last straw: Annapolis green seeks to reduce plastic straw use. TCA Regional News Retrieved from https://remotelib.ui.ac.id:2076/docview/2007459986? accountid=17242

[12]. Shown, M. (2018, Aug 16). Drink up: To straw or not to straw -- restaurants and beverage companies steer away from plastic straws and look for other options. TCA Regional News Retrieved from https://remote-lib.ui.ac.id:2076/docview/2088685707?accountid=17242

[13].Holman, J. T. (2005). The boston HIV-AIDS social movement: Framing, identity, and social movement decline (Order No. 3163357). Available from ProQuest Dissertations \& Theses Global. (305007508). Retrieved from https://remotelib.ui.ac.id:2076/docview/305007508?accountid $=17242$

[14].https://remote-lib.ui.ac.id:2076/docview/ 2125231885? Accounted $=17242$

[15]. Azuia tequila helps eliminate $20,000,000$ plastic straws with the no plastic straws 365 challenge. (2019, Jan 30). Global Data Point Retrieved from https://remotelib.ui.ac.id:2076/docview/2172632468? accountid $=17242$

[16].Caverly, I. T. (2019). Water, water everywhere, but not a straw to drink: How the americans with disabilities act serves as a limitation on plastic straw bans. Iowa Law Review, 105(1), 369397. Retrieved from https://search.proquest.com/docview/2346693398? accountid=17242

[17]. The final straw: Ben \& jerry's announces plan to eliminate single-use plastic in scoop shops worldwide. (2019, Jan 28). PR Newswire Retrieved from https://search.proquest.com/docview/2171633867?accountid=17242 